\title{
China's Sloping Land Conversion Program: Institutional Innovation or Business as Usual?
}

\author{
Michael T. Bennett ${ }^{\mathrm{a}}$ and Jintao $\mathrm{Xu}^{\mathrm{b}}$
}

\author{
${ }^{\mathrm{a}}$ Visiting Scholar and ${ }^{\mathrm{b}}$ Deputy Director, \\ Chinese Center for Agricultural Policy, Chinese Academy of Sciences, \\ Jia 11, Datun Rd., Chaoyang District, Beijing 100101, China. \\ Corresponding Author: mbennett.ccap@igsnrr.ac.cn
}

\begin{abstract}
China's Sloping Land Conversion Program (SLCP) is the largest land retirement program in the developing world, having the goal of converting 14.67 million hectares of cropland to forests by 2010 (4.4 million of which is on land with slopes greater than 25 degrees) and an additional "soft" goal of afforesting a roughly equal area of wasteland by 2010 (WWF, 2003; SFA, 2003). Pending successful completion it could represent a 10-20\% increase in China's national forest area and a $10 \%$ decrease in current cultivated area (Hyde, Belcher and $\mathrm{Xu}, 2003$; ZGTJNJ, 2001). At present the program is being implemented in more than 2000 counties across 25 provinces in China - a wide area containing huge ecological and economic heterogeneity - and involves the participation of tens of millions of rural households. The program has a total budget of RMB 337 billion (over US\$40 billion), around RMB 50 billion of which has been spent so far, and over 7.2 million hectares of cropland has been retired by the end of 2003 (Uchida et al., 2002; Xu and Cao, 2001; Tao, Xu and Xu, 2004). This case study draws upon past research of the program during its pilot phase (1999-2001) as well as a 2003 household and village-level survey conducted by the Center for Chinese Agricultural Policy, CAS, to examine program design, implementation and outcomes to date. We find significant problems in design and implementation in terms of the program's predominantly top-down approach and lack of true conditionality, differentiation and mechanisms to ensure permanence. We arguing that SLCP needs to be redesigned to allow for greater choice on the part of rural households as to whether or not to participate, greater local innovation and input, and utilization of market-based mechanisms to improve cost effectiveness and reduce adverse outcomes. Furthermore, policymakers need to recognize that the long-term nature of the environmental services targeted by the program require significant extension of the subsidy lengths, which at present are at most 8 years.
\end{abstract}

This research was funded by the Ford Foundation. The authors also wish to thank Scott Rozelle, Emi Uchida, Yazhen Gong and Jikun Huang for their help in designing and implementing the survey. All findings, opinions and mistakes contained within this manuscript are the sole responsibility of the authors. 


\section{Introduction}

Though China's policymakers have discussed cropland conversion programs for years, a severe Yellow River drought in 1997 and devastating floods along the middle and upper reaches of the Yangtze River spurred them to action. In reaction to these events, the central government initiated the Sloping Land Conversion Program in 1999, with particular emphasis on west China. Also known as Grain for Green, it is the largest land retirement program in the developing world, with the target of converting around 14.67 million hectares of cropland to forests (4.4 million of which is on land with slopes greater than 25 degrees) and an additional "soft” goal of afforesting a roughly equal area of wasteland by 2010 (WWF, 2003; SFA, 2003). As such, pending successful completion it could represent a $10-20 \%$ increase in China's national forest area and a 10\% decrease in current cultivated area (Hyde, Belcher and Xu, 2003; ZGTJNJ, 2001). At present the program is being implemented in more than 2000 counties across 25 provinces in China - a wide area containing huge ecological and economic heterogeneity - and involves the participation of tens of millions of rural households. The program has a total budget of RMB 337 billion (over US $\$ 40$ billion), around RMB 50 billion of which has been spent so far, and over 7.2 million hectares of cropland has been retired by the end of 2003 (Uchida et al., 2002; Xu and Cao, 2001; Tao, Xu and Xu, 2004).

This case study of SLCP draws from past research of the program during the pilot phase (1999-2001), and uses a 2003 household and village-level survey conducted by the Center for Chinese Agricultural Policy, Chinese Academy of Sciences, to generally examine program design, implementation and outcomes. ${ }^{1}$ It is important to note that in the backdrop of this discussion is significant variation in de facto local implementation of SLCP. As such, we

\footnotetext{
${ }^{1}$ The survey includes data on 360 households and 36 villages.
} 
highlight the key forms of implementation and design, while attempting to outline some of the range variation and its importance, where relevant.

\section{Services and actors}

The SLCP was initiated by the central government in 1999 with the stated environmental goals of reducing water and soil erosion and increasing China's forest cover and area by retiring steeply sloping and marginal lands from agricultural production. Soil erosion is one of China's most urgent environmental problems (Huang, 2000). An estimated 2 to 4 billion tons of silt is released into the Yangtze and the middle and upper reaches of the Yellow River annually, with around $65 \%$ of this coming from sloping cropland. Data suggests that west China, with $70 \%$ of the approximately 6.07 million ha of agricultural land with slopes greater than 25 degrees, contributes the majority of this (SFA, 2003; WWF, 2003).

Using the terminology of Wunder (2005), the program is a public scheme: it is fully paid for by the central government, with program finances being managed by the Ministry of Finance. Insofar as program environmental services exclusively benefit domestic recipients, the program buyer thus fully represents, in theory, its beneficiaries. However, if completed successfully, the program's future benefits could extend well beyond China's borders; it could result in an increase in current forest area by upwards of $10-20 \%$, which would have a large impact on domestic timber supply and thus - given China's large and growing footprint in international timber markets - on pressures on the world's forests (Hyde et al., 2002; Sun et al., 2004).

In recognition of the need for the program to be incentive-compatible for participants, SLCP 
also has the stated goals of poverty alleviation and assisting farm households shift to a more sustainable structure of production (SFA, 2003). The program also incorporates the goal long held by the central government - of afforesting and restoring barren and degraded wasteland and mountainous areas. During the pilot phase, this goal was an explicit requirement of participation, so that farmers retiring cropland were also required to afforest a certain amount of wasteland, though this appears to have varied significantly by locale. Given protests by participants of the significant labor requirements of this stipulation, the central government has since downgraded this to an optional, though encouraged, goal.

Added to this, Xu et al. (2005) argues that an additional hidden goal built into the program has been to subsidize the ailing State Grain Bureau. This is one of the more troubling aspects of the program, since it has likely influenced design and implementation. Xu et al. (2005) argue that the high grain subsidy that is part of program payments (discussed later in the paper) and the purchase of program grain from the State Grain Bureau (SGB) at RMB 0.4/kg above market prices have been deliberately designed to aid the SGB, and by the end of 2003 has resulted in a 24.55 million ton draw-down of stocks and an implicit RMB 9.8 billion subsidy. $^{2}$ This, furthermore, could in part have facilitated fast expansion of the program after the pilot phase.

Though significant regional variation exists, environmental service sellers have generally been selected based on whether or not their land falls into program targeted area. As detailed in Zuo (2001), targeting of areas to retire has generally been conducted via a top-down

\footnotetext{
2 The backdrop to this is the central government's failed grain policy during the 1990s, which involved large-scaled grain procurements at above-market prices and a subsequent failed attempt at recentralizing grain markets. This resulted, by 1999, in a State Grain Bureau burdened by severe financial stress and stocks of aging and unsold grain estimated to be larger than China’s annual production (Lu, 1998 \& 1999).
} 
approach, starting with retirement quotas that are distributed from the central government to the provinces, followed by subsequent distribution down through counties, townships, and finally to participating villages. As can be seen in Table 1 below, significant variation exists in the 2003 survey sample villages in terms of the degree to which various levels of government are involved in selection of area to retire and what to plant on retired land. The selection process is strongly influenced by China's structure of rural government, since only households in participant villages are able to participate, and as with many rural policies in China the onus of actual implementation falls to village and township government, with these serving as the key mediators between the central government (the buyer) and participant households (the sellers).

\section{[Table 1]}

Program compliance is defined in terms of the quality, type and survival rates of the trees/grasses planted on the enrolled land, with survival rates being adjusted for regional conditions. During the pilot phase, the stipulated survival rate for the southwestern region was $85 \%$ and for the northwestern/north central region was 70\%. Based on discussions with SFA officials, this has since been revised to a nationwide standard of $75 \%$ during full-scale implementation, though de facto standards appear subject to significant regional interpretation. ${ }^{3}$ An additional stipulation during the pilot phase has been that, in conjunction with retirement of cropland, a set proportion of wasteland must also be afforested, though with no survival rate conditions. According the SLCP plan, total retirement of cropland to afforested wasteland is 1:1.2 overall, with this varying from 1:1.02 for the Yangtze River

\footnotetext{
${ }^{3}$ Informal discussions with SFA officials, in fact, have revealed that these current survival rate standards, and other criteria used by the SFA's SLCP Office to categorize program forested area, conflict with those of the SFA's Department of Silviculture and Department of Forest Resources, the two entities generally responsible for managing China's afforestation initiatives.
} 
basin region to $1: 1.39$ for the Yellow River basin region. ${ }^{4}$ Compliance is monitored via a series of inspections conducted by various levels of government. These generally involve frequent inspections by village officials to ensure correct implementation, followed by formal evaluation by township and county governments to determine whether land passes inspection. As shown in Table 1 above, county and township government conducted inspections and verification in all villages in the 2003 survey. Random inspections by county or higher level government and inspections by the SFA are also conducted in some cases (Zuo, 2001; Xu and Cao, 2001).

Since the program plan makes significant allowances for diversity in local implementation, the degree to which compliance and outcomes are linked appears to be strongly contextual. Zuo (2001) notes that during the pilot phase officials have tended to focus on retiring contiguous swaths of land to convert to forests, and have taken into account ecological conservation, watershed services and the types of vegetation appropriate for local conditions when delineating areas for program enrollment. However, case studies during the pilot phase also found that most villages and townships have preferred the easier-to-implement method of simply targeting all steeply sloping cropland in the township rather than conducting targeting based on the conditions of entire catchments, and that in some cases plots closer to roads were targeted to "showcase" implementation to higher-level authorities (Zuo, 2001; Xu and Cao, 2001). However, Xu et al. (2005) finds that in the 2003 survey plot targeting has generally been good, with highly sloping, low-quality land being predominantly targeted.

Sanction mechanisms for non-compliance do not appear to be credible, indicating that the

\footnotetext{
${ }^{4}$ Zuo (2001) finds that in Inner Mongolia the stipulated proportion of cropland to wasteland afforestation was 1:3 in 2000, and 1:2 in 2001.
} 
program is not truly conditional. As Table 2 below indicates, survival rates of planted trees in many of the townships in the sample fell below those stipulated for subsidy delivery. Furthermore, survey results indicate that low survival rates have generally not resulted in the withholding of subsidies. The main reason for this, as Zuo (2001) and others have observed during the pilot phase, is the dual goals of environmental amelioration and poverty reduction, which place local leaders in the dilemma; withholding subsidies based on low survival rates can significantly dampen enthusiasm for the program and potentially harm participant welfare, while delivery without adhering to some indicators of compliance encourages poor implementation. Equally troubling is that the evaluation regime predominantly focuses on the direct indicators of implementation - number of trees planted, survival rates, whether or not funds have been disbursed - and has not looked at the broader picture of the degree to which the program is achieving its environmental goals (Zuo, 2001). Finally, that the program is not truly conditional can be seen in the finite and, indeed, short length of the subsidy period (discussed below).

\section{[Table 2]}

\section{Implementation}

Under SLCP, the State Forestry Administration plans to convert around 14.67 million hectares of cropland, 4.4 million of which is estimated to be on land with slopes of 25 degrees or above (SFA, 2003; WWF, 2003). ${ }^{5}$ The plan stipulates that retirement of cropland is to take place until 2010, with the subsidy period extending to 2017. The pilot phase was conducted from 1999-2001, followed by full-scale implementation. The pilot phase began with initial implementation in Shaanxi and Gansu provinces, located at the middle and upper

\footnotetext{
5 The program also has an additional a "soft" target of afforesting a roughly equivalent amount of denuded mountainous area and wasteland. However, this is voluntary and, in fact, simply represents a continuation of a longstanding policy.
} 
reaches of the Yellow River Basin, and Sichuan Province, located at the upper reaches of the Yangtze River Basin. By the end of the pilot, SLCP was being implemented 27,000 villages within 400 counties across 20 provinces, and a total of 1.2 million hectares of cropland had been converted and 0.47 million hectares of barren land (Xu et al. 2004; Uchida, Xu and Rozelle 2004). According to internal government reports, upon full implementation in 2002 SLCP was extended to a total of 1897 counties across 25 provinces, and by the end of 2003 the program had encompassed more than 2000 counties in 25 provinces. By the end of 2003, 7.1 million hectares of cropland had been converted, and 4.92 million hectares of barren land had been afforested (Xu et al. 2004).

During the pilot phase an average of 408,000 hectares of cropland was converted per year. Upon full-scale implantation beginning in 2002, however, this jumped to 2.9 million hectares per year, a more than sixfold increase. The number of enrolled counties also jumped significantly, by 374\% between the end of 2001 and the end of 2002. Fifteen million farmers have entered the program in just the first four years, and leaders have estimated that upon completion it will affect 40-60 million rural households (Uchida et al., 2004; Xu et al., 2004). Zhang et al. (2005) finds in a survey of investment projects during 1998-2003 in 2459 sample villages across 6 provinces in China that SLCP is the second most common project being implemented, behind road and bridge investments, at the village level.

Overall, SLCP is envisioned by policy makers as being complementary to its other forest sector policies, which are generally more command-and-control in nature. China's central government has long promoted forest and watershed protection/restoration projects, and SLCP falls within the State Forestry Administration's current six key programs (which are a 
consolidation of a previous ten programs). The other programs are the Natural Forest Protection Program, aimed at the state forestry sector, the Key Shelterbelt Development Program (in north China and the middle and lower reaches of the Yangtze River), the Program to Combat Desertification near Beijing and Tianjin, the Wildlife Conservation and Nature Reserve Development Program, and the Fast-Growing High-Yield Plantation Development Program (People’s Daily, 2002; WWF, 2004).

The only comparable program to SLCP is the Small Watersheds Program implemented by the Department of Water and Soil Conservation, Ministry of Water Resources (MWR). This project has been in effect for the past 20 or more years, and similar to SLCP involves the participation of rural households in a framework of integrated watershed management including afforestation/reforestation activities, small dam construction and terracing of land to reduce water erosion. SLCP, thus, represents an important shift of responsibilities for watershed management and restoration from the Ministry of Water Resources to the State Forestry Administration (SFA).

Subsidies for the program have until now been both in cash and in kind. The program stipulates that farmers who convert degraded and highly sloping cropland back to either “ecological forests” (defined by the State Forestry Administration as timber-producing forests), "economic forests" (orchards, or plantations of trees with medicinal value) or grassland will be compensated with 1) an annual in-kind subsidy of grain, 2) a cash subsidy, and 3) free seedlings, provided to the farmer at the beginning of the planting period. No formal pre-program analysis of participant opportunity cost was conducted; consideration of opportunity cost only comes into play in the regional differentiation of the in-kind subsidy. 
Specifically, based on estimates of average regional grain yields, the grain subsidy is set at $2250 \mathrm{~kg} / \mathrm{ha}$ in the Yangtze River Basin, and $1500 \mathrm{~kg} / \mathrm{ha}$ in the Yellow River Basin. The cash subsidy is RMB 300/ha of eligible land (US\$36/ha) per year. Both grain and cash subsidies are for 8 years if ecological forests are planted and for 5 years or 2 years if economic forests or grasses are planted, respectively (Xu et al., 2004). As of last year, however, the subsidy structure has since shifted so that farmers can be paid fully in cash. ${ }^{6}$ For afforestation of barren wasteland, a subsidy of RMB 750 per hectare ( US\$91) is provided. The SLCP plan also states that funds are to be earmarked to provide technical assistance for implementation, with these being determined case by case. Finally, all income derived from the forests and grasslands planted as part of SLCP is to be exempt from taxation (SFA, 2003).

Program payments are quite generous, even by international standards, and over the long term rural households in the localities where SLCP is being implemented will be some of the main beneficiaries (in addition to the downstream recipients of watershed services) of the future environmental services provided by the program. ${ }^{7}$ However, significant questions exist regarding whether or not the program has benefited participants in the short term. Uchida, Xu and Rozelle (2004) present evidence that compensation standards do not adequately account for regional and inter-household production variability, resulting in shortfalls in compensation to participant households in a number of cases. Results from the 2003 survey data support this. As detailed in Table 3 below, SLCP compensation standards are significantly below 1999 (pre-SLCP) net income of enrolled plots for many participants. In Gansu, this is the case for almost $50 \%$ of the participants in the sample, for a total shortfall

\footnotetext{
${ }^{6}$ This is due in no small part to the significant draw-down of State Grain Bureau stocks for program subsidies.

${ }^{7}$ In monetary terms compensation per hectare in the Yellow River and Yangtze River basins are around 1.9 times and 2.7 times, respectively, average rental payments of the US Conservation Reserve Program, which Heimlich (2003) estimates for 2000 to be US $\$ 45.62 /$ acre/year.
} 
of RMB 13,139, or an average at the household level of roughly $4 \%$ of 1999 net income. Calculation based on all participants in the Gansu sample, in fact, finds a total net loss of RMB 1,525. In Sichuan, compensation standards fell below 1999 net income from enrolled plots for around 29\% of participants in the sample, for a total shortfall of RMB 19,439, and in Shaanxi standards were below pre-program income for almost 7\% of participants, comprising an average shortfall equal to almost $45 \%$ of average 1999 net household income for these households.

\section{[Table 3]}

Even more troubling is evidence of significant shortfalls in subsidies actually delivered. Zuo (2001) finds several instances during the pilot phase where full compensation did not reach participating farmers. Fieldwork for the 2003 survey and another survey in Hunan Province also found serious diversion of funds slated for farmer compensation. In other cases, shortfalls are the result of plots that have been converted but have not yet been fully certified under SLCP. Xu and Cao (2001) find that in a group of 1026 households, fully 49.5\% had received only partial compensation, $8.5 \%$ had received only grain and $17.6 \%$ had received no compensation at the time of the survey. Uchida, Xu and Rozelle (2004) find in that around $24 \%$ and $77 \%$ of their sample households in Ningxia and Guizhou provinces, respectively, received payments less than pre-program net revenue from the plots. As detailed in Table 4 below, significant shortfalls in compensation received were also observed in the 2003 . Furthermore, these shortfalls do not appear to be the results of program lag time, since the maximum average shortfall (RMB 1507.5/ha) was in Yanchuan county, where implementation generally started earliest in the sample, while the minimum (RMB 480/ha) was found in Chaotian county in Sichuan, the province where implementation generally 
occurred latest.

\section{[Table 4]}

These shortfalls could in part symptomatic of one of the key obstacles to implementation: poor program budgeting. Shortfalls in some cases have been due deductions by village government to either pay laborers to plant trees on the farmer's converted land, or to pay for other administrative costs, or to pay back-taxes owed by the farmer (Zuo, 2001; Xu and Cao, 2001). Program coordination, inspection and compensation delivery for millions of plots is burdensome and costly for local governments, and yet the SLCP plan, dictates that local governments bear their own implementation costs. The central government has allocated some administrative fees to provincial governments for SLCP implementation since 2002, but these have been insufficient and are often in large part diverted by higher levels before reaching the townships. This is partially a result of the fast expansion of the program, which has created even greater administrative needs, and thus shortfalls in required administrative funds, and which has in turn led to problems in implementation and subsidy delivery. In a township in a key project county in Shaanxi Province, for example, half of the participating plots were not inspected and compensated on time. In another township of the same county, many participating plots had yet to be inspected even three years after they had entered SLCP; though the county government recruited 30 additional staff to deal with these problems, manpower has still been far short of that required to inspect some 67 thousand hectares of converted land.

Anecdotal evidence also suggests that some diversion of funds has been due to rent-seeking opportunities implicit in program design. Though the central government settled on the simplified, two-tier compensation scheme in part to prevent local governments from 
exploiting their informational advantage by exaggerating estimates of the forgone incomes of converted land so as to inflate their subsidies, local governments have nonetheless found other ways to milk the system by focusing their efforts on increasing their land conversion quotas, either through direct negotiation, or by first overreaching their land conversion quotas and then bargaining for more subsidies. ${ }^{8}$ Xu et al. (2005), for example, find evidence that villages with connections to local forest bureaus are able to obtain larger retirement quotas. Such behavior has existed since the beginning of the program, when the three pilot provinces of Sichuan, Shaanxi and Gansu overshot their quotas by more than $100 \%$ within 3-4 months. This continued through 2000, when 312 counties initiated land conversions on their own initiative, despite the fact that the central government's plan was to implement the pilot program in only 174 counties. To date, the State Forestry Administration continues to receive numerous requests from local governments asking for higher land conversion quotas.

Perhaps one of the most problematic aspects of implementation has been the primarily top-down approach taken towards implementation. As detailed in Table 5 below, only 43\% of participants in the 2003 survey indicated that villagers had been consulted by higher level authorities regarding program design and implementation before their village started SLCP. Furthermore, only around 53\% of surveyed households felt that they could choose whether or not to participate $\left(61.7 \%\right.$ of the participants and only $25.9 \%$ of non-participants). ${ }^{9}$ This ranges from $65.8 \%$ of households in Shaanxi, to $45.5 \%$ in Sichuan, to only $31 \%$ in Gansu Province. Participants felt they had even less choice in terms of how to adjust their structure

\footnotetext{
${ }^{8}$ This type of behavior is a continuing and significant issue in China's local public finance and governance system. It is due, in part, to significant shortfalls in local government finances, especially in less developed regions, due to significant lack of tax compliance and the decentralization of rural public finances (Wong, 2000).

9 These numbers do not change significantly when controlling for eligibility in terms of having sloping land. Fully $88 \%$ of the sample has land with slope $>15^{\circ}$, and $76.5 \%$ has land with slope $>25^{\circ}$.
} 
of production. Only 36\% said they could choose what kinds of trees to plant on their enrolled land. And only $34.5 \%$ and $29.9 \%$ of participant households felt that they could choose which areas and which plots, respectively, to retire. In Gansu Province, these numbers were only $15 \%$ and $13 \%$, respectively.

\section{[Table 5]}

These results not only run counter to the program's stated principals of volunteerism, but also suggest that the program is not fully obtaining the efficiency gains promised by payment for environmental services (PES) programs over traditional command-and-control approaches via use of a market-based, voluntary mechanism of participation (Pagiola et al., 2002). In the case of SLCP, since no bidding mechanism exists to optimally match payer benefits with participant costs, participation should, at minimum, be voluntary. This would improve cost effectiveness by ensuring that households with the lowest opportunity costs participate, and would minimize the possibility that some participants are being compensated less than their opportunity cost. As discussed above, evidence exists that this second, adverse outcome has already occurred.

\section{Additionality and baseline establishment:}

SLCP does indeed provide de facto additionality in terms of carbon sequestration, ecosystem services and timber supply, since without it farmers would not have retired the targeted cropland. However, the long-term extent of this is unclear, since it remains to be seen what share of afforested wasteland is viable in the long term and what share of retired cropland will be returned to cultivation after subsidies stop. As a rough gauge of this, Table 6 below looks at the responses of program participants in the 2003 survey to what they will most likely do after the subsidy period ends. Taken at face value, this suggests that around half of converted 
cropland will remain converted, which is troubling given the significant expenditures already made on the program, and since these results also suggest that potentially a fifth or more of cropland could be returned to cultivation upon subsidy period end.

\section{[Table 6]}

\section{Permanence, accounting and leakage:}

The only aspect of SLCP design that encourages permanence is the tax exempt status given to farmers on income earned from trees and grassland planted under the program. However, the short length of program subsidy periods likely more than offset any positive effects of this tax break. Added to this, there is nothing in the program design to prevent or reduce leakage. However, to date no research has examined whether or not, and to what degree leakage has occurred.

\section{Differentiation:}

In general, SLCP has been designed with little substantive differentiation. Apart from the two regional regimes and three subsidy lengths detailed above, program stipulations include little else that allows for differentiation across targeted areas and participants such as, for example, bidding mechanisms or a more varied menu of contract choices. Though participant opportunity cost and the provision of environmental services is somewhat implicit in the program's emphasis on sloping and degraded cropland, subsidies do not change based on indicators of environmental services provided such as, for example, plot slope. Implementation to date, furthermore, brings into question the program's stated regional focus on the important Yellow and Yangtze River basins, since by the end of 2003 SLCP was being implemented in over 2000 counties across 25 provinces. 
The degree to which targeting has raised administrative costs appears to depend crucially on local implementation. Xu et al. (2005) finds, however, that plot slope and land quality have been important factors in the targeting of plots, and that larger plots are preferentially chosen for retirement. This, combined with emphasis by local governments on retiring contiguous swaths of land, suggests that the targeting mechanism has potentially reduced transaction costs. At the same time, however, such costs could likely be further reduced by allowing for greater autonomy on the part of households in choosing whether or not to participate. Beyond that, introduction of more market-based mechanisms to better align ES provider costs with ES buyer benefits could help to reduce overall program costs and ensure that participants are not being adversely affected by the program.

\section{Participation of disadvantaged groups:}

In the context of China, where the huge inequalities in land rural distribution seen elsewhere are practically nonexistent, targeting of small landholders has not been an issue in program design. Uchida et al. (2004) and Xu et al. (2005) also find little evidence in the 2003 survey that poorer households within the areas where SLCP is being implemented are being predominantly targeted. That said, program emphasis on remote regions with high proportions of sloping and degraded land implicitly targets the poorer rural households in China. It is likely too early to say what the long-term impact of the program will be on participants and rural households in the locales where SLCP is being implemented. However, both Uchida et al. (2004) and Xu et al. (2005) - using standard program evaluation methodologies to examine SLCP impact on participant income using the 2003 survey - find impact on household per capita income to be insignificant, though also find weak evidence 
that the program has induced participants to shift agricultural production from cropping towards husbandry and other agricultural activities.

Overall, the dual goal of poverty alleviation appears to have adversely affected the program's environmental efficiency, since it allows local leaders to selectively deemphasize the program's environmental goals. In fact, the low survival rate of planted trees and fast rate of expansion with insufficient monitoring and evaluation suggest that if problems in design and implementation are not sufficiently addressed, the program will simply result in a one-off transfer to participants, with little substantive environmental outcomes. It is unclear what side benefits, if any, have resulted from SLCP. Though it is possible that implementation of SLCP has served to stimulate greater discussion at the local level of how best to deal with local resource degradation, such implementation has also been costly and time consuming for local leaders.

\section{Next steps}

At present, the government appears to be committed towards continuing implementation and expanding enrolled area according to the 2003 plan. SLCP officials, however, have also had to continually adjust program design in response to complaints made by local leaders, forestry officials and participant households. ${ }^{10}$ Local forestry authorities have complained about the heavy burden of implementation and monitoring, rural households who have not received their subsidies have been disgruntle, and results from the 2003 survey indicate that many participants feel that the subsidy period is too short. Overall, these appear to be the

\footnotetext{
${ }^{10}$ For example, this includes 1) changing afforestation of wasteland from a required goal during the pilot phase to an optional goal during full implementation, and 2) starting in 2002 to allocate funds to local governments to defray implementation costs.
} 
result of insufficient use of the pilot phase to identify and rectify problems in design and implementation, problems that fast-paced expansion has likely only served to exacerbate. However, the government has indicated that it plans to improve the quality of implementation and design. An example of this is a plan to establish processing facilities so that timber from SLCP-planted forests will be a viable source of income for participating households.

Overall, one of the most troubling aspects of SLCP is that, although on paper a PES scheme, in practice it appears to be just another top-down, campaign-style program with little input from local communities and households. The importance of farm households as the key long-term actors in implementation makes participant willingness and choice key conditions to program success. This could also help to reduce the likelihood of the adverse outcomes regarding participant compensation already observed. Introduction of more market-based mechanisms of implementation, such as bidding for contracts, could also significantly improve program cost effectiveness. In absence of such innovations, the program's lack of significant impact on participant income, and especially in non-cropping income found by Uchida et al. (2004) and Xu et al. (2005) suggests that those households that originally did not wish to participate, or who are not being adequately compensated for their opportunity costs of participation, will simply return land to cultivation upon subsidy period end. And results from the survey indicate that this is not a small share of participants.

Finally, the short subsidy periods of the program raise concerns that the government does not take seriously the permanence of the environmental services provided by SLCP. Though the 5-year subsidy period might give participants enough time to establish sustainable orchards or plantations of trees with medicinal value, the 8-year period for "ecological forests" (i.e. 
timber forests) is far too short. Most trees planted on converted land are ecological in nature (i.e. are not orchard trees) with limited potential economic returns in terms of their value for timber. Furthermore, the survival rates of the planted trees in ecologically fragile regions are quite low, and their required maturation period is far beyond the 8-year compensation period.

Overall, to realize these possibilities, officials need to significantly scale back program expansion and profoundly reexamining program design and implementation. Though the government's growing largesse towards environmental initiatives is encouraging, large-scale campaign-style programs are not the way to reverse adverse environmental outcomes stemming from a complex combination of factors. To capture the benefits in cost and outcomes promised by PES schemes over China’s more traditional, top-down approaches, mechanisms which encourage greater local initiative and autonomy should be built into SLCP, and the principals of volunteerism should be respected. Otherwise, SLCP could end up being an expensive, wasted opportunity. 


\section{References}

Heimlich, Ralph, 2003. Land Retirement. Chapter 6.2, Agricultural Resources and Environmental Indicators, 2003. Washington, D.C.: ERS, USDA.

Huang, Jikun, 2000. Land Degradation in China: Erosion and Salinity Component. CCAP Working Paper WP-00-E17. Center for Chinese Agricultural Policy, Beijing, China.

Hyde, William, Brian Belcher and Jintao Xu (Editors), 2003. China's Forests: Global Lessons from Market Reforms. Washington D.C.: Resources for the Future.

Lu, Feng, 1999. Three Grain Surpluses - Evolution of China's Grain Price and Marketing Policies (1978-1999). International Agricultural Trade Research Consortium, China’s Agricultural Trade and Policy: Issues, Analysis, and Global Issues. San Francisco, California.

Lu, Feng, 1998. Grain versus Food: A Hidden Issue in China’s Food Policy Debate. World Development 26(9): 1641-1652.

Pagiola, Stafano, Natasha Landell-Mills and Joshua Bishop, 2002. "Making Market-Based Mechanism Work for Forests and People.” In Stafano Pagiola, Joshua Bishop and Natasha Landell-Mills (Eds.), Selling Forest Environmental Services: Market-Based Mechanisms for Conservation and Development. London, UK: Earthscan.

People’s Daily, 2002. Six Major Afforestation Projects All Kicked Off In China. Peoples Daily, August 02. http://english.people.com.cn/200208/02/eng20020802_100804.shtml.

SFA (State Forestry Administration), 2003. Sloping Land Conversion Program Plan (2001-2010) [In Chinese].

Sun, Xiufang, Eugenia Katsigris and Andy White, 2004. Meeting China’s Demand for

Forest Products: An Overview of Import Trends, Ports of Entry, and Supplying Countries, with Emphasis on the Asia-Pacific Region. China and Forest Trade in the Asia-Pacific Region: Implications for Forests and Livelihoods. Forest Trends.

Tao, Ran, Zhigang Xu and Jintao Xu, 2004. Grain for Green Project, Grain Policy and Sustainable Development [In Chinese]. Social Sciences in China 150: 25-38.

Uchida, Emi, Jintao Xu and Scott Rozelle, 2004. Grain for green: cost-effectiveness and sustainability of China's conservation set-aside program. Land Economics, forthcoming.

Uchida, Emi, Jintao Xu, Zhigang Xu and Scott Rozelle, 2004. Are the Poor Benefiting from China's Land Conversion Program? Mimeo.

Wong, Christine, 2000. Central-local relations revisited: The 1994 tax sharing reform and public expenditure management in China. China Perspectives 31: 52-63.

World Wildlife Fund (WWF), 2003. [Internet, cited June 5, 2005]. http://www.wwfchina.org/english/loca.php?loca=159.

Wunder, S., 2005. Payments for Environmental Services: Some Nuts and Bolts. CIFOR Occasional Paper No. 42.

$\mathrm{Xu}$, Jintao and Yiying Cao, 2001. The Socioeconomic Impacts and Sustainability of 
the SLCP. In: Jintao Xu, Eugenia Katsigris and Thomas A. White (Editors), Implementing the Natural Forest Protection Program and the Sloping Land Conversion Program: Lessons and Policy Recommendations. CCICED-Task Force on Forests and Grasslands. China Forestry Publishing House: Beijing.

$\mathrm{Xu}$, Jintao, Eugenia Katsigris and Thomas A. White (Editors), 2001. Implementing the Natural Forest Protection Program and the Sloping Land Conversion Program: Lessons and Policy Implications. CCICED-WCFGTF (China Council for International Cooperation on Environment and Development, Western China Forests and Grassland Task Force). China Forestry Publishing House: Beijing.

$\mathrm{Xu}$, Jintao, Ran Tao, Zhigang Xu and Michael Bennett, 2005. China’s Sloping Land Conversion Program: Does Expansion Equal Success? CCAP Working Paper.

Xu, Zhigang, Michael Bennett, Ran Tao and Jintao Xu, 2004. China’s Sloping Land Conversion Program Four Years On: Current Situation, Pending Issues. The International Forestry Review. Special Issue: Forestry in China - Policy, Consumption and Production in Forestry's Newest Superpower. 6(3-4): 317-326.

ZGTJNJ [China Statistical Yearbook], 2001. Beijing: China Statistical Press.

Zhang, Linxiu, Renfu Luo, Chengfang Liu and Scott Rozelle, 2005. Investing in Rural China: Tracking China’s Commitment to Modernization. Working Paper, Center for Chinese Agricultural Policy, CAS.

Zuo, T., 2001. Part II. The Sloping Land Conversion Program (SLCP). Chapter 3. Implementation of the SLCP. In: J. Xu, E. Katsigris and T. A. White (Editors), Implementing the Natural Forest Protection Program and the Sloping Land Conversion Program: Lessons and Policy Implications. CCICED-WCFGTF. Beijing Forestry Publishing House, Beijing, pp49-70. 
Workshop on "Payments for Environmental Services (PES) - Methods and Design in Developing 22 and Developed Countries.”

Table 1 SLCP Implementation in 2003 Survey Sample Villages

\begin{tabular}{|c|c|c|c|c|}
\hline Question to Village Leader & $\begin{array}{c}\text { Total } \\
(n=36)\end{array}$ & $\begin{array}{l}\text { Shaanxi } \\
(n=12)\end{array}$ & $\begin{array}{l}\text { Gansu } \\
(n=12)\end{array}$ & $\begin{array}{r}\text { Sichuan } \\
(n=12)\end{array}$ \\
\hline \multicolumn{5}{|l|}{ Who decides how much land area should be retired? } \\
\hline Province & $0 \%$ & $0 \%$ & $0 \%$ & $0 \%$ \\
\hline County & $25 \%$ & $25 \%$ & $25 \%$ & $25 \%$ \\
\hline Township & $50 \%$ & $8.3 \%$ & $58.3 \%$ & $83.3 \%$ \\
\hline Village & $13.9 \%$ & $16.7 \%$ & $25 \%$ & $0 \%$ \\
\hline Village Small Groups & $0 \%$ & $0 \%$ & $0 \%$ & $0 \%$ \\
\hline Households & $22.2 \%$ & $50 \%$ & $8.3 \%$ & $8.3 \%$ \\
\hline Other & $0 \%$ & $0 \%$ & $0 \%$ & $0 \%$ \\
\hline \multicolumn{5}{|l|}{ Who decides which plots to retire? } \\
\hline Province & $0 \%$ & $0 \%$ & $0 \%$ & $0 \%$ \\
\hline County & $16.7 \%$ & $16.7 \%$ & $0 \%$ & $33.3 \%$ \\
\hline Township & $52.8 \%$ & $16.7 \%$ & $58.3 \%$ & $83.3 \%$ \\
\hline Village & $36.1 \%$ & $33.3 \%$ & $58.3 \%$ & $16.7 \%$ \\
\hline Village Small Groups & $2.8 \%$ & $0 \%$ & $8.3 \%$ & $0 \%$ \\
\hline Households & $16.7 \%$ & $41.7 \%$ & $8.3 \%$ & $0 \%$ \\
\hline Other & $0 \%$ & $0 \%$ & $0 \%$ & $0 \%$ \\
\hline \multicolumn{5}{|l|}{ Who decides what to plant on retired land? } \\
\hline Province & $0 \%$ & $0 \%$ & $0 \%$ & $0 \%$ \\
\hline County & $66.7 \%$ & $41.7 \%$ & $58.3 \%$ & $100 \%$ \\
\hline Township & $19.4 \%$ & $16.7 \%$ & $41.7 \%$ & $0 \%$ \\
\hline Village & $5.6 \%$ & $8.3 \%$ & $8.3 \%$ & $0 \%$ \\
\hline Village Small Groups & $0 \%$ & $0 \%$ & $0 \%$ & $0 \%$ \\
\hline Households & $11.1 \%$ & $33.3 \%$ & $0 \%$ & $0 \%$ \\
\hline Other & $2.8 \%$ & $0 \%$ & $8.3 \%$ & $0 \%$ \\
\hline \multicolumn{5}{|l|}{ Who conducts inspections and verifications? } \\
\hline County & $100 \%$ & $100 \%$ & $100 \%$ & $100 \%$ \\
\hline Township & $100 \%$ & $100 \%$ & $100 \%$ & $100 \%$ \\
\hline Village & $2.8 \%$ & $8.3 \%$ & $0 \%$ & $0 \%$ \\
\hline Other & $97.2 \%$ & $91.7 \%$ & $100 \%$ & $100 \%$ \\
\hline \multicolumn{5}{|l|}{ Share of villages that ... } \\
\hline ...distribute SLCP quotas to households. & $61.1 \%$ & $25 \%$ & $58.3 \%$ & $100 \%$ \\
\hline ...distribute SLCP quotas to village small groups. & $60 \%$ & $27.3 \%$ & $50 \%$ & $100 \%$ \\
\hline ...are allocated SLCP quotas by township government. & $75 \%$ & $41.7 \%$ & $83.3 \%$ & $100 \%$ \\
\hline
\end{tabular}


Workshop on "Payments for Environmental Services (PES) - Methods and Design in Developing and Developed Countries.”

Table 2: Average Survival Rate of Trees Planted Under SLCP (\%), 2003 Survey.

\begin{tabular}{|c|c|c|c|c|c|c|}
\hline \multirow{2}{*}{ Province } & \multirow{2}{*}{ County } & \multirow{2}{*}{ Township } & \multirow{2}{*}{$\begin{array}{c}\text { Govt. } \\
\text { Standard }\end{array}$} & \multicolumn{3}{|c|}{ Inspections } \\
\hline & & & & $1^{\text {st }}$ & $2^{\text {nd }}$ & $3^{\text {rd }}$ \\
\hline \multirow{6}{*}{ Shaanxi } & \multirow{3}{*}{ Yanchuan } & Yanshuiguan & \multirow{6}{*}{$70 \%$} & $94.2 \%$ & $93.6 \%$ & $98 \%$ \\
\hline & & Majiahe & & $72.9 \%$ & $95.8 \%$ & $96.4 \%$ \\
\hline & & Yuju & & $79 \%$ & $83.2 \%$ & $95 \%$ \\
\hline & \multirow{3}{*}{ Liquan } & Yanxia & & $56.3 \%$ & $86.8 \%$ & $81.1 \%$ \\
\hline & & Jianling & & $78.8 \%$ & $47.9 \%$ & $39.4 \%$ \\
\hline & & Chigan & & $100 \%$ & $46.7 \%$ & $52.1 \%$ \\
\hline \multirow{6}{*}{ Gansu } & \multirow{3}{*}{ Jingning } & Zhigan & \multirow{6}{*}{$70 \%$} & $70 \%$ & $69 \%$ & $66 \%$ \\
\hline & & Gangou & & $80 \%$ & $76.6 \%$ & $71 \%$ \\
\hline & & Lingzhi & & - & $75.7 \%$ & $77.7 \%$ \\
\hline & \multirow{3}{*}{ Linxia } & Zhangzigou & & $56.3 \%$ & $46.7 \%$ & $65 \%$ \\
\hline & & \begin{tabular}{|l|} 
Tiezhai \\
\end{tabular} & & $90 \%$ & $61.1 \%$ & $75.8 \%$ \\
\hline & & Hexi & & $87.5 \%$ & $69.5 \%$ & $64 \%$ \\
\hline \multirow{6}{*}{ Sichuan } & \multirow{3}{*}{$\begin{array}{c}\text { Chaotian } \\
\text { Area }\end{array}$} & Datan & \multirow{6}{*}{$85 \%$} & $82 \%$ & $61.5 \%$ & $67.3 \%$ \\
\hline & & Zhongzi & & $70 \%$ & $48.7 \%$ & $77 \%$ \\
\hline & & Shahe & & $92.5 \%$ & $74.1 \%$ & $40.4 \%$ \\
\hline & \multirow{3}{*}{$\mathrm{Li}$} & Shangmeng & & $100 \%$ & $79.6 \%$ & $76.1 \%$ \\
\hline & & Puxi & & $74.9 \%$ & $80.7 \%$ & $84.8 \%$ \\
\hline & & Guergo & & $70 \%$ & $74.1 \%$ & $77 \%$ \\
\hline
\end{tabular}

Source: 2003 Survey Data

TABLE 3 Participant 1999 Net Income from Enrolled Land Versus SLCP Compensation Standards

\begin{tabular}{|c|c|c|c|c|}
\hline & & $\begin{array}{l}\text { Net Losing } \\
\text { Households }\end{array}$ & $\begin{array}{l}\text { Net Gaining } \\
\text { Households }\end{array}$ & All Participants \\
\hline \multirow{3}{*}{$\begin{array}{l}\text { mิ } \\
\text { ๖ } \\
\text { II } \\
\text { s }\end{array}$} & Number of Households & 7 & 96 & 103 \\
\hline & Total 1999 Net Income from Enrolled Land (RMB) & 322 & 12 & 34 \\
\hline & Total Converted Land Area ( $\mathrm{Ha})$ & 5.13 & 68.13 & 73.27 \\
\hline \multirow{2}{*}{ 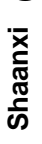 } & Compensation Standard - 1999 Net Income (RMB) & $-14,778$ & 120,478 & 105,700 \\
\hline & Average Net Gain as \% of Total Compensation & $-120 \%$ & $74 \%$ & $60 \%$ \\
\hline \multirow{5}{*}{ 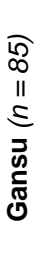 } & Number of Households & 40 & 45 & 85 \\
\hline & Total 1999 Net Income from Enrolled Land (RMB) & 239 & 65 & 135 \\
\hline & Total Converted Land Area ( $\mathrm{Ha})$ & 8.07 & 11.93 & 20 \\
\hline & Compensation - 1999 Net Income (RMB) & $-13,139$ & 11,614 & $-1,525$ \\
\hline & Average Net Gain as \% of Total Compensation & $-68 \%$ & $41 \%$ & $-3 \%$ \\
\hline \multirow{5}{*}{ 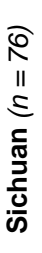 } & Number of Households & 22 & 54 & 76 \\
\hline & Total 1999 Net Income from Enrolled Land (RMB) & 364 & 70 & 164 \\
\hline & Total Converted Land Area (Ha) & 7.27 & 15.47 & 22.73 \\
\hline & Compensation - 1999 Net Income (RMB) & $-19,439$ & 26,657 & 7,218 \\
\hline & Average Net Gain as \% of Total Compensation & $-85 \%$ & $55 \%$ & $10 \%$ \\
\hline
\end{tabular}

Source: Xu et al. , 2005. 
Workshop on "Payments for Environmental Services (PES) - Methods and Design in Developing 24 and Developed Countries.”

TABLE 4 Average Shortfalls in Grain and Cash Compensation in Surveyed Areas, 2002

\begin{tabular}{|c|c|c|c|c|c|c|}
\hline \multirow[b]{2}{*}{ Province } & \multirow[b]{2}{*}{ County } & \multicolumn{2}{|c|}{ Grain $(k g / h a)^{+}$} & \multicolumn{2}{|c|}{ Cash (RMB / ha) } & \multirow{2}{*}{$\begin{array}{l}\text { Total Shortfall } \\
(R M B / h a)^{++}\end{array}$} \\
\hline & & $\begin{array}{c}\text { SLCP } \\
\text { Standard }\end{array}$ & $\begin{array}{l}\text { Actual } \\
\text { Delivery }\end{array}$ & $\begin{array}{c}\text { SLCP } \\
\text { Standard }\end{array}$ & $\begin{array}{l}\text { Actual } \\
\text { Delivery }\end{array}$ & \\
\hline \multirow{2}{*}{ Shaanxi } & Yanchuan & 1500 & 232.5 & 300 & 60 & 1507.5 \\
\hline & Liquan & 1500 & 1215 & 300 & 90 & 495 \\
\hline \multirow{2}{*}{ Gansu } & Jingning & 1500 & 810 & 300 & 255 & 735 \\
\hline & Linxia & 1500 & 322.5 & 300 & 30 & 1447.5 \\
\hline \multirow{2}{*}{ Sichuan } & Chaotian & 2250 & 2025 & 300 & 45 & 480 \\
\hline & Lixian & 2250 & 1927.5 & 300 & 195 & 427.5 \\
\hline Average: & & 1763 & 810 & 300 & 105 & 1148 \\
\hline
\end{tabular}

Source: Xu et al., 2005. + This is a sum of corn, wheat and rise subsidies. ++ This values grain at the national price of RMB $1 / \mathrm{kg}$.

Table 5 Farmer autonomy in SLCP participation $(n=348)$

\begin{tabular}{|c|c|c|c|c|c|}
\hline \multirow[b]{2}{*}{ GROUP } & \multirow[b]{2}{*}{ MEASURE OF AUTONOMY } & \multicolumn{4}{|c|}{ \% THAT SAID "YES" } \\
\hline & & ALL & $\begin{array}{l}\text { Shaanxi } \\
(n=103)\end{array}$ & $\begin{array}{l}\text { Gansu } \\
(n=85)\end{array}$ & $\begin{array}{l}\text { Sichuan } \\
(n=76)\end{array}$ \\
\hline \multirow{5}{*}{$\begin{array}{l}\text { PARTICIPANTS } \\
\quad(n=264)\end{array}$} & $\begin{array}{l}\text { Were the villagers asked their opinion about the project and how it } \\
\text { could be best designed prior to the time that the project was } \\
\text { implemented? }\end{array}$ & $42.8 \%$ & $41.7 \%$ & $41.2 \%$ & $46.1 \%$ \\
\hline & $\begin{array}{l}\text { When you village began SLCP, did your household have } \\
\text { autonomy to choose whether or not to participate? }\end{array}$ & $61.7 \%$ & $72.8 \%$ & $43.5 \%$ & $67.1 \%$ \\
\hline & $\begin{array}{l}\text { Did you have autonomy in choosing } \\
\text { the types of trees to plant? }\end{array}$ & $36.0 \%$ & $47.6 \%$ & $34.1 \%$ & $22.4 \%$ \\
\hline & $\begin{array}{l}\text { Did you have autonomy in choosing } \\
\text { which areas to retire? }\end{array}$ & $34.5 \%$ & $53.4 \%$ & $15.3 \%$ & $30.3 \%$ \\
\hline & $\begin{array}{l}\text { Did you have autonomy in choosing } \\
\text { which plots to retire? }\end{array}$ & $29.9 \%$ & $40.8 \%$ & $12.9 \%$ & $34.2 \%$ \\
\hline \multirow{2}{*}{$\begin{array}{l}\text { NON- } \\
\text { PARTICIPANTS } \\
(n=81)\end{array}$} & & ALL & $\begin{array}{l}\text { Shaanxi } \\
(n=11)\end{array}$ & $\begin{array}{l}\text { Gansu } \\
(n=34)\end{array}$ & $\begin{array}{l}\text { Sichuan } \\
(n=36)\end{array}$ \\
\hline & Could you participate in SLCP if you wanted to? & $25.9 \%$ & $45.5 \%$ & $29.4 \%$ & $16.7 \%$ \\
\hline
\end{tabular}


Workshop on "Payments for Environmental Services (PES) - Methods and Design in Developing 25 and Developed Countries.”

Table 6: Pariticipants' Viewpoints on their Post-SLCP Activities.

\begin{tabular}{|c|c|c|c|c|}
\hline \multirow{2}{*}{$\begin{array}{l}\text { Question: } \\
\text { "lf program subsidies stop after 5-8 years, what do you most } \\
\text { likely intend to do?" }\end{array}$} & \multicolumn{4}{|c|}{$\%$ of Participants / \% of Retired Area } \\
\hline & 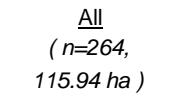 & $\begin{array}{l}\frac{\text { Shaanxi }}{(n=103,} \\
73.24 \text { ha })\end{array}$ & $\begin{array}{c}\frac{\text { Gansu }}{(n=85,} \\
19.97 \text { ha })\end{array}$ & $\begin{array}{l}\frac{\text { Sichuan }}{(n=76,} \\
22.73 \text { ha })\end{array}$ \\
\hline Promising & $\underline{57.6 \%}$ I $\underline{54.2 \%}$ & $\underline{51.5 \%}$ I $\underline{52.0 \%}$ & $\underline{76.5 \%}$ I $\underline{76.9 \%}$ & $\underline{44.7 \%}$ I $\underline{41.3 \%}$ \\
\hline $\begin{array}{l}\text { Allow timber trees / orchard trees to reach maturity for } \\
\text { harvesting. }\end{array}$ & $20.8 \% / 23.7 \%$ & $24.3 \%$ / 26.3\% & $21.2 \%$ / 22.1\% & $15.8 \% / 16.8 \%$ \\
\hline $\begin{array}{l}\text { Can maintain livelihood with revenue from current activities } \\
\text { [non-farm business / aquaculture / livestock / orchards]. }\end{array}$ & $36.7 \%$ / 30.5\% & $27.2 \%$ / $25.8 \%$ & $55.3 \% / 54.8 \%$ & $29.0 \% / 24.4 \%$ \\
\hline Ambiguous & $\underline{20.1 \%} \underline{\underline{25.7} \%}$ & $\underline{27.2 \%}$ I $\underline{29.7 \%}$ & $\underline{14.1 \%}$ I $\underline{12.2 \%}$ & $\underline{17.1 \%}$ I $\underline{24.4 \%}$ \\
\hline Continue farming. & $0.8 \% \quad / \quad 0.2 \%$ & $0.0 \% \quad / \quad 0.0 \%$ & $2.4 \%$ / $1.1 \%$ & $0.0 \% / \quad 0.0 \%$ \\
\hline Find work in the city. & $12.5 \% / 17.0 \%$ & $17.5 \% / 18.5 \%$ & $10.6 \% / 10.7 \%$ & $7.9 \% / 18.0 \%$ \\
\hline Start a new non-agricultural activity. & $5.3 \% / 6.9 \%$ & $6.8 \% / 8.9 \%$ & $1.2 \% / \quad 0.3 \%$ & $7.9 \% / 6.1 \%$ \\
\hline Other (no clarification given). & $1.5 \% / \quad 1.5 \%$ & $2.9 \% / 2.3 \%$ & $0.0 \% / \quad 0.0 \%$ & $1.3 \% / \quad 0.3 \%$ \\
\hline Problematic & $\underline{22.4 \%}$ ！ $\underline{20.1 \%}$ & $\underline{21.4 \% ！ \mid 18.2 \%}$ & $\underline{9.4 \%} ｜ \underline{11.0 \%}$ & $38.2 \%$ ! $34.3 \%$ \\
\hline Don't know. & $14.8 \% / 13.8 \%$ & $9.7 \%$ / $10.4 \%$ & $8.2 \% / 10.9 \%$ & $29.0 \% / 27.5 \%$ \\
\hline Assume/hope subsidies, of some type, will continue. & $1.5 \% / \quad 0.8 \%$ & $0.0 \%$ / $0.0 \%$ & $0.0 \% \quad / \quad 0.0 \%$ & $5.3 \% / 4.1 \%$ \\
\hline If not making adequate income, will return plots to cultivation. & $1.5 \% / \quad 0.5 \%$ & $3.9 \% / 0.9 \%$ & $0.0 \% / \quad 0.0 \%$ & $0.0 \% / \quad 0.0 \%$ \\
\hline Return currently retired plots to cultivation. & $4.6 \% / 5.0 \%$ & $7.8 \% / 7.0 \%$ & $1.2 \% \quad / \quad 0.1 \%$ & $4.0 \% / 2.8 \%$ \\
\hline
\end{tabular}

Source: 2003 Survey Data 